\title{
Antioxidant enzymes and non-enzymatic antioxidants as defense mechanism of salinity stress in cowpea (Vigna unguiculata L. Walp)- Ife brown and Ife bpc
}

\author{
Foluso Ologundudu*
}

\begin{abstract}
Background: Several mechanisms had been exhibited by plants to mitigate deleterious effects of salinity stress. A screen house experiment was conducted to investigate the effects of salinity stress on the activities of osmolytes (antioxidative and non-antioxidative enzymes) in the leaves of two cowpea (Vigna unguiculata L. Walp) - Ife brown and Ife $b p c$, with the aim of better understanding the biochemical mechanisms of salt tolerance. Salts of sodium chloride $(\mathrm{NaCl})$ and sodium sulfate $\left(\mathrm{Na}_{2} \mathrm{SO}_{4}\right)$ at 5,10 and $15 \mathrm{dS} / \mathrm{m}$ concentrations were used for this study. The saline solution was prepared following standard methods. Proline, lipid peroxidase (LP), superoxide dismutase (SOD) and glutathione (GSH) were determined following standard protocols.

Results: Results showed that minimum proline content $(12.07 \mathrm{mg} / \mathrm{g})$ and maximum proline determination $\left(16.05 \mathrm{mg} / \mathrm{g}\right.$ ) were observed in Ife bpc at 5 and at $15 \mathrm{dS} / \mathrm{m}$ under $\mathrm{NaCl}$ and $\mathrm{Na}_{2} \mathrm{SO}_{4}$ treatments. The LP content significantly increased in Ife brown at $15 \mathrm{dS} / \mathrm{m}$ under $\mathrm{NaCl}$ treatment and at $10 \mathrm{dS} / \mathrm{m}(9.49 \mathrm{mg} / \mathrm{g})$ under $\mathrm{Na}_{2} \mathrm{SO}_{4}$ salinity. Minimum GSH content $(120 \mu \mathrm{m} / \mathrm{g})$ and maximum glutathione accumulation $(138.97 \mu \mathrm{m} / \mathrm{g})$ were observed in Ife bpc in the stressed cowpea seedlings ( 5 and $10 \mathrm{dS} / \mathrm{m}$ ) under $\mathrm{NaCl}$ treatment with respect to the control. Also, SOD activities in the leaves of Ife brown increase with increase in salinity stress in both $\mathrm{NaCl}$ and $\mathrm{Na}_{2} \mathrm{SO}_{4}$ treatments.
\end{abstract}

Conclusions: This study concludes that the accumulation of enzymatic and non-enzymatic antioxidants is capable of detoxifying and scavenging reactive oxygen species, thereby mitigating salinity-induced oxidative damage.

Keywords: Antioxidants, Defense mechanism, Oxidative damage, Salinity, Scavenging

\section{Background}

The fundamental mechanism of salinity effect on plant function is the increase in osmotic pressure of the plants environment that inhibits the absorption of water and nutrients (Borzouei et al. 2012). Invariably, salinity inhibits photosynthesis through its effect on stomatal conductance, water and nutrient uptake and decrease in chlorophyll concentration (Khare et al. 2020; Hu et al.

*Correspondence: akinbodefoluso@gmail.com

Botany Unit, Department of Biology, Federal University of Technology, Akure, Nigeria
2020). Mechanisms exhibited by plants to mitigate the deleterious effects of salinity include: compartmentalization of ions, synthesis of compatible solutes (osmolytes), induction of plant hormones and alteration of membrane structure (Zainab et al. 2021). During the initial stages of salinity stress, water absorption capacity of root system decreases and water loss from leaves is accelerated due to osmotic stress of high salt accumulation (Zhao et al. 2015; Bhatt 2020). Proline is a water-soluble amino acid classified as a compatible osmolyte, i.e., it does not damage cell structures at high concentrations, but is capable of lowering the cell osmotic potential (Ibrahim et al. 
2018). It performs multiple functions in stress adaptation, recovery and signaling, stabilization of proteins and protein complexes in the chloroplast, cytosol and protection of the photosynthetic apparatus in plants (Ozgur et al. 2013). Bacha et al. (2017) suggested that the application of proline successfully improved stress tolerance in plants. Production of reactive oxygen species (ROS) has been touted as one of the biochemical changes possibly occurring when plants are subjected to salinity stress (Hu et al. 2020). The photosynthetic apparatus is an important site for the production of such radicals which include superoxide $\left(\mathrm{O}_{2}^{-}\right)$, hydrogen peroxide $\left(\mathrm{H}_{2} \mathrm{O}_{2}\right)$ and hydroxyl radicals (Naveed et al. 2020). These ROS disrupt normal cellular metabolism through membrane alteration and damage to lipids, proteins and nucleic acids (Naveed et al. 2020). Plants have developed complex defense mechanism involving a series of enzymatic antioxidants, such as catalase (CAT), glutathione (GSH), superoxide dismutase (SOD), ascorbate peroxidase (APX) and guaiacol peroxidase (GPX), and non-enzymatic antioxidants which include ascorbate, carotenoids, flavonoids and other phenolics to mitigate the deleterious effects of oxidative damage (Bacha et al. 2017). Superoxide dismutase (SOD) plays an important role in scavenging of hydroxyl radicals imposed by oxidative damage (Ozgur et al. 2013; Gharsallah et al. 2016). Thus, SOD is regarded as a key enzyme for maintaining normal physiological function and managing oxidative stress in ROS (Aref and Rad 2012). Glutathione is abundant in several eukaryotic organisms where it performs plethora of functions, which include sulfide transport and regulation of redox potential of intracellular organelles (Rahman et al. 2016; Zainab et al. 2021). It is a potent reductant capable of scavenging ROS directly or in conjunction with other antioxidants (Sharma et al. 2012; Ibrahim et al. 2018). Membrane damage is sometimes regarded as an indicator of lipid destruction under various stresses (Aref and Rad 2012). Malondialdehyde (MDA) is synthesized as a result of degradation of polyunsaturated lipids by ROS. This aldehyde production has been used as an important biomarker to determine the level of oxidative stress (Khare et al. 2020). Therefore, this study investigated the effects of salinity stress on the activities of osmolytes (antioxidative and non-antioxidative enzymes) in the leaves of two cowpea (Vigna unguiculata L. Walp)-Ife brown and Ife bpc. This is with the aim of better understanding the biochemical mechanisms of salt tolerance.

\section{Methods}

\section{Plant material}

Seeds of cowpea (Vigna unguiculata L. Walp), namely Ife brown and Ife bpc, were utilized in the experiment. The seeds were collected from International institute of
Tropical Agriculture (IITA), Ibadan, Nigeria. They were authenticated at the Herbarium unit of the Federal University of Technology Akure, Nigeria.

\section{Soil and pre-planting analysis}

The soil was collected at the school farm of the Federal university of Technology Akure. The following physicochemical properties of the soil were determined: particle size and textural class, organic carbon, organic matter, $\mathrm{pH}$, total nitrogen, available phosphorus, potassium, sodium, calcium, magnesium, effective cation exchange capacity and exchangeable acidity. The soil was later airdried and transferred into 48 plastic pots of about $21 \mathrm{~cm}$ diameter and $17 \mathrm{~cm}$ depth. The pots were perforated to enhance drainage during the course of the experiment.

\section{Screen house experiment}

The experimental setup was located in the screen house. The essence is to monitor the plant growth and to avoid being destroyed by rodents, contaminations and direct rainfall.

\section{Preparation of salt solution}

Salts of sodium chloride $(\mathrm{NaCl})$ and sodium sulfate $\left(\mathrm{Na}_{2} \mathrm{SO}_{4}\right)$ were used for this study. The saline solution was prepared following standard methods of Meot-Duros and Magne (2008).

\section{Experimental design}

A $2 \times 2 \times 4 \times 3$ randomized complete block design (RCBD) was adopted. The experimental factors include salt type $\left(\mathrm{NaCl}\right.$ and $\left.\mathrm{Na}_{2} \mathrm{SO}_{4}\right)$, variety (Ife brown and Ife bpc) and salt concentrations (control, $5 \mathrm{dS} / \mathrm{m}, 10 \mathrm{dS} / \mathrm{m}$ and $15 \mathrm{dS} / \mathrm{m}$ and replicated three times.

\section{Experimental setup}

The experiment was conducted at the screen house of the Department of Biology, Federal University of Technology Akure. About $5 \mathrm{~kg}$ of air-dried soils was filled into perforated plastic pots. Five (5) seeds of cowpea varieties (Ife brown and Ife bpc) were sown in each pot and watered regularly until the plants were fully established.

\section{Salinity treatment}

Salinization commenced four (4) weeks after planting, and each pot was administered with $200 \mathrm{ml}$ of saline solution every three days till the end of the experimental period.

\section{Non-enzymatic antioxidants assay Lipid peroxidation}

Lipid peroxidation in fresh cowpea leaf samples was determined by estimating the malondialdehyde (MDA) 
following standard protocols of (Zeb and Ullah 2016). About $1 \mathrm{~g}$ of frozen leaf samples was ground to a fine powder with liquid nitrogen and extracted with ice-cold $50 \mathrm{mM}$ phosphate buffer ( $\mathrm{pH}$ 7.0). Centrifugation of the homogenate was done for ten minutes, and $0.5 \mathrm{ml}$ of the supernatant was then mixed with $1.5 \mathrm{ml}, 0.5 \%$ thiobarbituric acid (TBA). Incubation of the supernatant was done in a water bath at $95{ }^{\circ} \mathrm{C}$ for $25 \mathrm{~min}$. The concentration of MDA was determined from the absorbance at $532 \mathrm{~nm}$ (correction factor was applied by subtracting the absorbance at $600 \mathrm{~nm}$ for unspecific turbidity) by using extinction coefficient of $155 \mathrm{mM}^{-1} \mathrm{~cm}^{-1}$.

\section{Proline determination}

$0.5 \mathrm{~g}$ of leaf samples from each variety was homogenized in $3 \%(\mathrm{w} / \mathrm{v})$ sulfosalicylic acid, and the homogenate filtered was then filtered using Whatman's filter paper following standard methods of Bates et al. (1973). The mixture was heated at $100{ }^{\circ} \mathrm{C}$ for $1 \mathrm{~h}$ in water bath after acid ninhydrin and glacial acetic acid have been added. The reaction was then stopped by ice bath. The mixture was extracted with toluene, and the absorbance of fraction aspired from liquid phase was read at $520 \mathrm{~nm}$. Proline concentration was determined using calibration curve and expressed as $\mu \mathrm{mol}$ proline $\mathrm{g}^{-1} \mathrm{FW}$.

\section{Glutathione (GSH)}

The method of Beutler et al. (1963) was adopted in the estimation of the level of reduced glutathione (GSH) in the leaves of cowpea. Sample homogenate $(0.2 \mathrm{ml})$ was added to $1.8 \mathrm{ml}$ of distilled water, and $3 \mathrm{ml}$ of the precipitating agent, sulfosalicylic acid, was mixed with the sample. This was centrifuged at 3,000 g for $4 \mathrm{~min}$. Thereafter, $0.5 \mathrm{ml}$ of the supernatant was added to $4.5 \mathrm{ml}$ of Ellman reagent. A blank was prepared with $0.5 \mathrm{ml}$ of the diluted precipitating agent and $4 \mathrm{ml}$ of phosphate buffer and $0.5 \mathrm{ml}$ of Ellman's reagent. The absorbance of the reaction mixture was taken within 30 min of color development at $412 \mathrm{~nm}$ against a reagent blank. The concentration of the GSH was extrapolated from the GSH standard curve.

\section{Antioxidant enzyme assays}

\section{Superoxide dismutase (SOD)}

Total SOD (EC 1.15.1.1) activity was determined by measuring its ability to inhibit the photochemical reduction of nitrotetrazolium blue chloride (NBT), as described by Giannopolitis and Ries (1977). The reaction mixture $(1.5 \mathrm{~mL})$ contained $50 \mathrm{mM}$ phosphate buffer $(\mathrm{pH}$ 7.8), $0.1 \mu \mathrm{M}$ ethylenediaminetetraacetic acid (EDTA), $13 \mathrm{mM}$ methionine, $75 \mu \mathrm{M}$ NBT, $2 \mu \mathrm{M}$ riboflavin and 50 $\mu \mathrm{L}$ enzyme extract. Riboflavin was added, and the tubes were subjected to mechanical shaker and later illuminated with two 20 -W fluorescent tubes. The reaction was allowed to proceed for 15 min after which the lights were switched off and the tubes covered with a black cloth. Absorbance of the reaction mixture was read at $560 \mathrm{~nm}$. One unit of SOD activity $(\mathrm{U})$ was defined as the amount of enzyme required to cause $50 \%$ inhibition of the NBT photoreduction rate, and the results were expressed as units $\mathrm{mg}^{-1}$ protein.

\section{Statistical analysis}

Data collected were subjected to one-way analysis of variance (ANOVA), and means were separated with Duncan Multiple Range Test (DMRT) at 0.05 probability level (SPSS version 21.0).

\section{Results}

Proline accumulations in the leaves of Ife brown (IFB) and Ife bpc (IBPC) under $\mathrm{NaCl}$ and $\mathrm{Na}_{2} \mathrm{SO}_{4}$ salinity are shown in Table 1 . Minimum proline content $(12.07 \mathrm{mg} / \mathrm{g})$ and maximum proline determination $(16.05 \mathrm{mg} / \mathrm{g})$ were observed in Ife bpc at 5 and at $15 \mathrm{dS} / \mathrm{m}$ under $\mathrm{NaCl}$ and $\mathrm{Na}_{2} \mathrm{SO}_{4}$ treatments. There was significant difference in the proline content of Ife brown and Ife bpc at $15 \mathrm{dS} / \mathrm{m}$ under both treatments. Also, there was significant difference in the maximum proline $(14.85 \mathrm{mg} / \mathrm{g})$ that was recorded in Ife brown at $5 \mathrm{dS} / \mathrm{m}$ relative to the control.

Lipid peroxidase (LP) accumulations in the leaves of Ife brown (IFB) and Ife bpc (IBPC) under $\mathrm{NaCl}$ and $\mathrm{Na}_{2} \mathrm{SO}_{4}$ salinity are shown in Table 2. Maximum lipid peroxidation was recorded in Ife bpc at $5 \mathrm{dS} / \mathrm{m}$ under $\mathrm{Na}_{2} \mathrm{SO}_{4}$ treatment. However, minimum MDA content was also noticeable in Ife brown at $10 \mathrm{dS} / \mathrm{m}$ under $\mathrm{Na}_{2} \mathrm{SO}_{4}$ salinity. The LP content significantly increased in Ife brown at 15 $\mathrm{dS} / \mathrm{m}$ under $\mathrm{NaCl}$ treatment and at $10 \mathrm{dS} / \mathrm{m}(9.49 \mathrm{mg} / \mathrm{g})$ under $\mathrm{Na}_{2} \mathrm{SO}_{4}$ salinity. Meanwhile, Ife bpc did not record

Table 1 Proline accumulations in the leaves of Ife brown (IFB) and Ife bpc (IBPC) under $\mathrm{NaCl}$ and $\mathrm{Na}_{2} \mathrm{SO}_{4}$ salinity stress

\begin{tabular}{lcll}
\hline Treatment & Conc (dS/m) & $\begin{array}{l}\text { Biochemical parameters } \\
\text { (mean } \pm \text { SE) }\end{array}$ \\
\cline { 3 - 4 } & & IFB proline $(\mathbf{m g} / \mathbf{g})$ & $\begin{array}{l}\text { IFBPC proline } \\
\text { (mg/g) }\end{array}$ \\
\hline $\mathrm{NaCl}$ & 5.00 & $13.06 \pm 0.14 \mathrm{~b}$ & $16.05 \pm 0.04 \mathrm{~d}$ \\
& 10.00 & $14.15 \pm 0.40 \mathrm{bc}$ & $12.69 \pm 0.03 \mathrm{~b}$ \\
& 15.00 & $14.53 \pm 0.42 \mathrm{~cd}$ & $12.07 \pm 0.04 \mathrm{a}$ \\
$\mathrm{Na}_{2} \mathrm{SO}_{4}$ & 5.00 & $14.85 \pm 0.21 \mathrm{~d}$ & $15.76 \pm 0.00 \mathrm{e}$ \\
& 10.00 & $13.75 \pm 0.19 \mathrm{~b}$ & $14.38 \pm 0.04 \mathrm{~d}$ \\
& 15.00 & $12.94 \pm 0.24 \mathrm{a}$ & $13.34 \pm 0.04 \mathrm{c}$ \\
Distilled $\mathrm{H}_{2} \mathrm{O}$ & 0.0 & $13.77 \pm 0.05 \mathrm{~b}$ & $14.26 \pm 0.43 \mathrm{~d}$ \\
\hline
\end{tabular}

Means followed by different letters in the column are significantly different $(P<0.05)$ from one another using Duncan's new multiple range test (DNMRT) 
Table 2 Lipid peroxidase (LP) accumulations in the leaves of Ife brown (IFB) and Ife bpc (IBPC) under $\mathrm{NaCl}$ and $\mathrm{Na}_{2} \mathrm{SO}_{4}$ salinity stress

\begin{tabular}{lcll}
\hline Treatment & Conc $(\mathbf{d S} / \mathbf{m})$ & $\begin{array}{l}\text { Biochemical parameters } \\
\text { (mean } \pm \mathbf{S E})\end{array}$ \\
\cline { 3 - 4 } & & $\begin{array}{l}\text { IFB lipid } \\
\text { peroxidase } \\
\text { (mg/g) }\end{array}$ & $\begin{array}{l}\text { IFBPC lipid } \\
\text { peroxidase } \\
(\mathbf{m g} / \mathbf{g})\end{array}$ \\
\hline $\mathrm{NaCl}$ & 5.00 & $1.29 \pm 0.02 \mathrm{a}$ & $1.63 \pm 0.03 \mathrm{a}$ \\
& 10.00 & $5.37 \pm 0.29 \mathrm{c}$ & $5.91 \pm 0.06 \mathrm{~d}$ \\
& 15.00 & $6.02 \pm 0.25 \mathrm{~d}$ & $5.33 \pm 0.03 \mathrm{C}$ \\
$\mathrm{Na}_{2} \mathrm{SO}_{4}$ & 5.00 & $1.40 \pm 0.03 \mathrm{a}$ & $9.49 \pm 0.01 \mathrm{f}$ \\
& 10.00 & $1.10 \pm 0.03 \mathrm{a}$ & $4.58 \pm 0.16 \mathrm{~b}$ \\
& 15.00 & $6.82 \pm 0.06 \mathrm{e}$ & $8.70 \pm 0.03 \mathrm{e}$ \\
Distilled $\mathrm{H}_{2} \mathrm{O}$ & 0.0 & $3.20 \pm 0.17 \mathrm{~b}$ & $1.63 \pm 0.13 \mathrm{a}$ \\
\hline
\end{tabular}

Means followed by different letters in the column are significantly different

$(P<0.05)$ from one another using Duncan's new multiple range rest (DNMRT)

any induction of lipid peroxidase at $5 \mathrm{dS} / \mathrm{m}$ under $\mathrm{NaCl}$ treatment.

Glutathione (GSH) contents in the leaves of Ife brown (IFB) and Ife bpc (IBPC) under $\mathrm{NaCl}$ and $\mathrm{Na}_{2} \mathrm{SO}_{4}$ salinity are shown in Table 3. Minimum GSH content $(120 \mu \mathrm{m} / \mathrm{g})$ and maximum glutathione accumulation $(138.97 \mu \mathrm{m} / \mathrm{g})$ were observed in Ife bpc in the stressed cowpea seedlings ( 5 and $10 \mathrm{dS} / \mathrm{m}$ ) under $\mathrm{NaCl}$ treatment with respect to the control. Maximum GSH $(134 \mu \mathrm{m} / \mathrm{g})$ was also recorded in Ife brown at $15 \mu \mathrm{m} / \mathrm{g}$ under $\mathrm{NaCl}$ treatment. The minimum GSH content $(125.75 \mu \mathrm{m} / \mathrm{g})$ in Ife brown was observed at $5 \mathrm{dS} / \mathrm{m}$ under $\mathrm{NaCl}$ treatment. There were significant differences in the GSH accumulations for Ife brown at $15 \mathrm{dS} / \mathrm{m}$ under $\mathrm{NaCl}$ and $\mathrm{Na}_{2} \mathrm{SO}_{4}$ stresses. Significant increase was also recorded in Ife bpc at 5 $\mathrm{dS} / \mathrm{m}$ under $\mathrm{NaCl}$ and $\mathrm{Na}_{2} \mathrm{SO}_{4}$ treatments.

Superoxide dismutase (SOD) activities in the leaves of Ife brown (IFB) and Ife bpc (IBPC) under $\mathrm{NaCl}$ and $\mathrm{Na}_{2} \mathrm{SO}_{4}$ salinity are shown in Table 4 . SOD activities in

Table 3 Glutathione (GSH) contents in the leaves of Ife brown (IFB) and Ife bpc (IBPC) under $\mathrm{NaCl}$ and $\mathrm{Na}_{2} \mathrm{SO}_{4}$ salinity stress

\begin{tabular}{lccl}
\hline Treatment & Conc $(\mathbf{d S} / \mathbf{m})$ & \multicolumn{2}{c}{ Biochemical parameters (mean $\pm \mathbf{S E})$} \\
\cline { 3 - 4 } & & IFB GSH $(\boldsymbol{\mu m} / \mathbf{g})$ & IFBPC GSH $(\boldsymbol{\mu m} / \mathbf{g})$ \\
\hline $\mathrm{NaCl}$ & 5.00 & $125.75 \pm 0.11 \mathrm{~b}$ & $138.97 \pm 0.11 \mathrm{~d}$ \\
& 10.00 & $130.42 \pm 0.12 \mathrm{~d}$ & $123.65 \pm 0.13 \mathrm{ab}$ \\
& 15.00 & $132.29 \pm 0.21 \mathrm{e}$ & $120.64 \pm 0.12 \mathrm{a}$ \\
$\mathrm{Na}_{2} \mathrm{SO}_{4}$ & 5.00 & $128.52 \pm 0.13 \mathrm{c}$ & $138.29 \pm 0.12 \mathrm{~d}$ \\
& 10.00 & $126.04 \pm 0.26 \mathrm{~b}$ & $131.49 \pm 0.12 \mathrm{c}$ \\
& 15.00 & $123.81 \pm 0.23 \mathrm{a}$ & $125.30 \pm 0.87 \mathrm{~b}$ \\
Distilled $\mathrm{H}_{2} \mathrm{O}$ & 0.0 & $127.37 \pm 1.36 \mathrm{bc}$ & $131.91 \pm 2.76 \mathrm{c}$ \\
\hline
\end{tabular}

Means followed by different letters in the column are significantly different $(P<0.05)$ from one another using Duncan's new multiple range test (DNMRT)
Table 4 Superoxide dismutase (SOD) activities in the leaves of Ife brown (IFB) and Ife bpc (IBPC) under $\mathrm{NaCl}$ and $\mathrm{Na}_{2} \mathrm{SO}_{4}$ salinity stress

\begin{tabular}{lcll}
\hline Treatment & Conc $(\mathbf{d S} / \mathbf{m})$ & \multicolumn{2}{l}{$\begin{array}{l}\text { Biochemical parameters } \\
\text { (mean } \pm \text { SE) }\end{array}$} \\
\cline { 3 - 4 } & & IFB SOD (\%) & IFBPC SOD (\%) \\
\hline $\mathrm{NaCl}$ & 5.00 & $38.87 \pm 0.18 \mathrm{~b}$ & $45.24 \pm 1.37 \mathrm{~d}$ \\
& 10.00 & $42.11 \pm 0.27 \mathrm{c}$ & $42.86 \pm 0.01 \mathrm{~cd}$ \\
& 15.00 & $48.81 \pm 0.20 \mathrm{~d}$ & $28.67 \pm 0.06 \mathrm{~b}$ \\
$\mathrm{Na}_{2} \mathrm{SO}_{4}$ & 5.00 & $36.16 \pm 2.38 \mathrm{c}$ & $38.19 \pm 1.37 \mathrm{ab}$ \\
& 10.00 & $45.76 \pm 0.19 \mathrm{~d}$ & $26.59 \pm 1.38 \mathrm{a}$ \\
& 15.00 & $51.10 \pm 0.01 \mathrm{e}$ & $21.06 \pm 0.02 \mathrm{c}$ \\
Distilled $\mathrm{H}_{2} \mathrm{O}$ & 0.0 & $51.50 \pm 2.89 \mathrm{e}$ & $46.03 \pm 4.20 \mathrm{~d}$ \\
\hline
\end{tabular}

Means followed by different letters in the column are significantly different

$(P<0.05)$ from one another using Duncan's new multiple range test (DNMRT)

the leaves of Ife brown increase with increase in salinity stress in both $\mathrm{NaCl}$ and $\mathrm{Na}_{2} \mathrm{SO}_{4}$ treatments. There were significant differences in the SOD activities for Ife brown at $10 \mathrm{dS} / \mathrm{m}$ under $\mathrm{NaCl}$ and $\mathrm{Na}_{2} \mathrm{SO}_{4}$ treatments. Significant differences were also recorded in Ife bpc at $15 \mathrm{dS} / \mathrm{m}$ under $\mathrm{NaCl}$ and $\mathrm{Na}_{2} \mathrm{SO}_{4}$ treatments. SOD activities in the stressed seedlings of both varieties were found to be lower compared to the control seedlings.

\section{Discussion}

The structural stability and osmotic adjustment of proline during stress had been an important indicator of oxidative damage in plants (Michael and Krishnaswamy 2012). Miranda et al. (2014) previously reported proline accumulations in response to various stresses in leaf in many studies. The observed maximum proline accumulations in IBPC under $\mathrm{NaCl}$ and $\mathrm{Na}_{2} \mathrm{SO}_{4}$ are in agreement with these findings. Cellular architecture releases compatible osmolytes to maintain cell turgor and osmoregulation. Compatible osmolytes act as stabilizer by cushioning the effect of oxidative damage to macromolecules by salinity stress (Gharsallah et al. 2016). The increased MDA content in IFB under both treatments possibly indicates that IFB is capable of maintaining high degree of cell membrane homeostasis under high salt stress. Osmotic adjustment remained an integral factor and an important physiological character associated with salinity tolerance. This mechanism had attracted much attention and generated much debate during the past years. The observed minimum MDA content recorded in Ife brown (IFB) at 10 $\mathrm{dS} / \mathrm{m}$ under $\mathrm{Na}_{2} \mathrm{SO}_{4}$ stress possibly demonstrates that the IFB displays higher antioxidative ability, thereby reflecting higher salinity tolerance. This is in agreement with the findings of Sharma et al. (2012). Ozgur 
et al. (2013) reported that increase in reactive oxygen species (ROS) and lipid peroxidation is indicators of the decrease in antioxidant defenses. Osmotic adjustment simply involves the differential accumulation of compatible solutes in a cell in response to a decrease in solute potential of the cell's environment (Rahman et al. 2016). Oxidative damage necessitated by salinity stress is mitigated by a combined action of both enzymatic and non-enzymatic antioxidant systems. These include $\alpha$-tocopherol ( $\alpha$-toc), $\beta$-carotenes, carotenoids, ascorbate (ASC), reduced glutathione (GSH), enzymes including superoxide dismutase (SOD), peroxidase (POD), ascorbate peroxidase (APX), catalase (CAT), polyphenol oxidase (PPO) and glutathione reductase (GR). Superoxide radicals are produced in various physiological processes under conditions of abiotic stress (Das et al. 2014). The observed increase in SOD activities in IFB under $\mathrm{NaCl}$ treatment is an indication that SOD is capable of mitigating effect of oxidative stress in cowpea seedlings. An increase in the activities of antioxidative enzymes under salt and water stress possibly indicates an increased production of reactive oxygen species (ROS). Findings from this research are in agreement with Karuppanapandian et al. (2011), who reported that increased production of ROS is capable of developing mechanisms to reduce oxidative damage in plants. It is widely perceived that the biosynthesis of many secondary metabolites in plants is an important part of the defense response to stress conditions (Isah 2019). The increase in glutathione activities in response to salinity stress in IFB may possibly be connected with increased stress tolerance (Khare et al. 2020). Stress tolerance is a complex phenomenon involving coordinated response that includes ion sequestration, metabolic adjustment and antioxidative defense (Abogadallah 2010). Salinity-induced alterations and disruptions in the physiology and biochemistry of the plant may elicit metabolic disturbances that trigger an abundant production of the product of oxidative damage (Naveed et al. 2020).

\section{Conclusions}

The increased proline content in IBPC confers structural stability to cellular machinery by acting as osmolyte capable of detoxifying reactive oxygen species (ROS) toward ameliorating salinity-induced damage in cowpea seedlings. The increased lipid peroxidation content in IFB suggests that the variety is capable of acting as osmoprotectant against membrane damage by salinity stress. The accumulation of superoxide dismutase (SOD) and glutathione (GSH) in IFB clearly demonstrates that enzymatic and non-enzymatic antioxidants are capable of scavenging reactive oxygen species, thereby mitigating salinity-induced oxidative damage in cowpea.

\section{Acknowledgements \\ The researchers want to appreciate the technical and academic staff of the Department of Biology, Federal University of Technology, Akure, Nigeria.}

\section{Authors' contributions}

The author read and approved the final manuscript.

\section{Funding}

There was no funding for this research.

\section{Declarations}

Ethics approval and consent to participate

Not applicable.

Consent for publication

Not applicable.

\section{Competing interest}

The author declare that he has no competing interest.

Received: 29 June 2021 Accepted: 7 September 2021 Published online: 13 September 2021

\section{References}

Abogadallah GM (2010) Insights into the significance of antioxidative defense under salt stress. Plant Signal Behav 5(4):369-374. https://doi.org/10. 4161/psb.5.4.10873

Aref F, Rad HE (2012) Physiological characterization of rice under salinity stress during vegetative and reproductive stages. Indian J Sci Technol 5(4):2578-2586. https://doi.org/10.17485/IJST/2012/N5/4/30427

Bacha H, Tekaya M, Drine S, Guasmi F, Touil L, Enneb H, Triki T, Cheour F, Ferchichi A (2017) Impact of salt stress on morpho-physiological and biochemical parameters of Solanum lycopersicum cv. Microtom leaves. South Afr J Bot 108:364-369. https://doi.org/10.1016/j.sajb.2016.08.018

Bates LS, Waldren RP, Teare ID (1973) Rapid determination of free proline for water-stress studies. Plant Soil 39(1):205-207. https://doi.org/10.1007/ BF00018060

Beutler E, Duron O, Kelly BM (1963) Improved method for the determination of glutathione. J Labor Clin Med 61:882-888

Bhatt T (2020) Salt tolerance mechanisms and approaches: future scope of halotolerant genes and rice landraces. Rice Sci 27(5):368-383

Borzouei A, Kafi M, Akbari-Ghogdi E, Mousavi-Shalmani M (2012) Long term salinity stress in relation to lipid peroxidation, super oxide dismutase activity and proline content of salt-sensitive and salt-tolerant wheat cultivars. Chil J Agric Res 72(4):476-482. https://doi.org/10.4067/s071858392012000400003

Das K, Roychoudhury A, Anjum NA (2014) Reactive oxygen species (ROS) and response of antioxidants as ROS-scavengers during environmental stress in plants. https://doi.org/10.3389/fenvs.2014.00053

Gharsallah C, Fakhfakh H, Grubb D, Gorsane F (2016) Effect of salt stress on ion concentration, proline content, antioxidant enzyme activities and gene expression in tomato cultivars. https://doi.org/10.1093/aobpla/plw055

Giannopolitis N, Ries SK (1977) Superoxide dismutase. I. Occurrence in higher plants. J Plant Physiol 59:309-314

Hu B, Deng F, Chen G, Chen X, Gao W, Long L, Xia J, Chen ZH (2020) Evolution of abscisic acid signaling for stress responses to toxic metals and metalloids. Front Plant Sci 11:1-16. https://doi.org/10.3389/fpls.2020.00909

Ibrahim AM, Lawal B, Abubakar AN, Tsado NA, Kontagora GN, Gboke JA, Berinyuy EB (2018) Antimicrobial and free radical scavenging potentials of $\mathrm{N}$-hexane and ethyl acetate fractions of Phyllanthus fraternus. Nig J Bas Appl Sci 25:2-6. https://doi.org/10.4314/njbas.v25i2.2

Isah T (2019) Stress and defense responses in plant secondary metabolites production. Bio Res 52(1):39-45. https://doi.org/10.1186/s40659-019-0246-3 
Karuppanapandian T, Moon JC, Kim C, Manoharan K, Kim W (2011) Reactive oxygen species in plants: their generation, signal transduction, and scavenging mechanisms. Aust J Crop Sci 5(6):709-725

Khare S, Singh NB, Singh A, Hussain I, Niharika K, Yadav V, Bano C, Yadav RK, Amist N (2020) Plant secondary metabolites synthesis and their regulations under biotic and abiotic constraints. J Plant Biol 63(3):203-216. https://doi.org/10.1007/s12374-020-09245-7

Meot-Duros L, Magne C (2008) Effect of salinity and chemical factors on seed germination in the halophyte (Crithmum maritimum L.). Plant Soil 313:83-87

Michael PI, Krishnaswamy M (2012) Oxidative stress and antioxidants in cowpea plants subjected to boron and high irradiance stresses. J Plant Nutr 35(14):2180-2197. https://doi.org/10.1080/01904167.2012.724498

Miranda D, Fischer G, Mewis I, Rohn S, Ulrichs C (2014) Salinity effects on proline accumulation and total antioxidant activity in leaves of the cape gooseberry (Physalis peruviana L.). J Appl Bot Food Qual 87:67-73. https:// doi.org/10.5073/JABFQ.2014.087.010

Naveed M, Sajid H, Mustafa A, Niamat B, Ahmad Z, Yaseen M, Kamran M, Rafique M, Ahmar S, Chen JT (2020) Alleviation of salinity-induced oxidative stress, improvement in growth, physiology and mineral nutrition of canola (Brassica napus L.) through calcium-fortified composted animal manure. Susty 12(3):1-17. https://doi.org/10.3390/su12030846

Ozgur R, Uzilday B, Sekmen AH, Turkan I (2013) Reactive oxygen species regulation and antioxidant defence in halophytes. Funct Plant Biol 40(9):832-847. https://doi.org/10.1071/FP12389
Rahman A, Shahadat Hossain M, Mahmud JA, Nahar K, Hasanuzzaman M (2016) Manganese-induced salt stress tolerance in rice seedlings: regulation of ion homeostasis, antioxidant defense and glyoxalase systems. Physiol Mol Biol Plants 22:34-42. https://doi.org/10.1007/ s12298-016-0371-1

Sharma P, Jha AB, Dubey RS, Pessarakli M (2012) Reactive oxygen species, oxidative damage, and antioxidative defense mechanism in plants under stressful conditions. J Bot. https://doi.org/10.1155/2012/217037

Zainab Q, Muhammad TC, Xiongming D, Lori H, Muhammad TA (2021) Review of oxidative stress and antioxidative defense mechanisms in Gossypium hirsutum L. in response to extreme abiotic conditions. J Cot Res 4:9-13. https://doi.org/10.1186/s42397-021-00086-4

Zeb A, Ullah F (2016) A simple spectrophotometric method for the determination of thiobarbituric acid reactive substances in fried fast foods. J Anal Methods Chem. https://doi.org/10.1155/2016/9412767

Zhao X, Wang J, Yuan J, Wang XL, Zhao QP, Kong PT, Zhang X (2015) Nitric oxide-associated protein1 (AtNOA1) is essential for salicylic acid-induced root waving in Arabidopsis thaliana. New Phytol 207:211-224. https://doi. org/10.1111/nph.13327

\section{Publisher's Note}

Springer Nature remains neutral with regard to jurisdictional claims in published maps and institutional affiliations.

\section{Submit your manuscript to a SpringerOpen ${ }^{\odot}$ journal and benefit from:}

- Convenient online submission

- Rigorous peer review

- Open access: articles freely available online

- High visibility within the field

- Retaining the copyright to your article

Submit your next manuscript at $\boldsymbol{\nabla}$ springeropen.com 